\title{
Embedding built heritage values in architectural design education
}

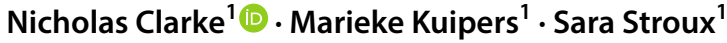

Accepted: 19 June 2019 / Published online: 1 August 2019

(c) The Author(s) 2019

\begin{abstract}
Continuity and change have become crucial themes for the built environment and heritage buildings; also in the education and practice of architects. Embedding built heritage values into studio-based design education is a daunting new challenge that demands new didactic perspectives and tools. To address the dilemmas that come with design assignments for adaptive reuse, an experiment with new didactic analytical tools has been conducted in the Heritage \& Architecture (H\&A) architectural design studios at the Delft University of Technology. The analysis attempts to connect matter-physical structures - and meaning in a structured graphical process through predefined mapping exercises. Our aim is to introduce a step-by-step method for exploration that can form the foundation of valuesbased design from built heritage. Central to our multifaceted approach is a specially developed matrix that is meant to support design-oriented analysis of heritage buildings. This paper situates the H\&A perspective on the adaptive reuse of valorised buildings within the heritage discourse and architectural design education in general and further gives insight into the didactics, the tools, their uses and initial results. After a critical reflection on our points of departure, based in an evaluation of results, peer discussion and student evaluation, we conclude that the applied methodology is instructive to the educational goals but also merits further development. One of the lessons learnt for future teaching includes allowing students freedom to discover values themselves. An important conclusion is that an earlier and broader foundation that engages the continuation of tangible and intangible heritage values in the ever-changing built environment is required in architectural educational practice.
\end{abstract}

Keywords Built heritage $\cdot$ Valuation $\cdot$ Adaptive reuse $\cdot$ Critical observation $\cdot$ Design orientated research methodologies $\cdot$ Values-based design education

Nicholas Clarke

n.j.clarke@tudelft.nl

Marieke Kuipers

m.c.kuipers@tudelft.nl

Sara Stroux

s.a.stroux@tudelft.nl

1 Chair of Heritage and Values, Faculty of Architecture and the Built Environment/Heritage \& Architecture, Delft University of Technology, Juliana Avenue 134, Delft, The Netherlands 


\section{Introduction}

Architects are rediscovering that their profession forms part of a long tradition. As a case in point, British starchitect, Sir Norman Foster, explained his views on architecture and values in a 2014 interview: 'Architecture is a connection with the past. However, our concern is not for relics but for the revitalization of historic buildings, repurposing them for a new generation. Architecture can communicate memory, but it can also communicate values and a sense of place... Architecture is an expression of values - the way we build is a reflection of the way we live. This is why vernacular traditions and the historical layers of a city are so fascinating, as every era produces its own vocabulary. Sometimes we have to explore the past to find inspiration for the future. At its most noble, architecture is the embodiment of our civic values[...]' (Rosenfield 2014).

We are not only experiencing a general increase in the awareness of the social value of buildings in the built environment professions in general; adaptive reuse of existing built fabric is becoming more and more prevalent in Western Europe. Cramer and Breitling (2012) report that between 50 and $70 \%$ of all construction work concerns interventions in existing buildings. This is not only a response to a growing awareness of the cultural importance of built fabric, but also a response to the ecological impacts of the construction process within a wider understanding of sustainability (Van Hees et al. 2014). The real estate of the future, in fact, already exists and architects therefore need to know how to address the existing (Kuipers and De Jonge 2017). This is especially so when dealing with valorised buildings, townscapes or sensitive settings. Architectural reuse has become urgently relevant to the design education of architects.

The transition from new-build to reuse developments and from conservation to adaptation in built heritage has implications for the education of that architect. It requires architects to have knowledge of both the physical qualities and insufficiencies of an existing building as well as the values embodied by the building, which in turn requires innovation in teaching practice. This recent rise in complexity in approaches to existing built fabric is mirrored in the transition of the erstwhile Chair of Restoration at the Delft University of Technology (TU Delft) into the three complementary chairs of Heritage and Design, Heritage and Technology and Heritage and Values that today collaborate in the section of Heritage \& Architecture (H\&A). ${ }^{1}$

The creation of a Chair of Heritage and Values demands that methods be developed to embed (cultural-) heritage values in architectural design education (Clarke and Kuipers 2017). The various values embodied by (heritage-) buildings are well defined and have critically been studied during the past decades, particularly for listing, but 'there is little knowledge about how, pragmatically, the whole range of heritage values can be assessed in the context of planning and decision making' (Mason 2005, p. 5).

\footnotetext{
1 The current Chair of Heritage and Values was formerly known as Heritage and Cultural Value. The educational programme was developed in collaboration with the former Chair of Cultural Heritage, in particular of the architecture of the $20^{\text {th }}$ century, held by Prof emer. Marieke Kuipers until July 2017.
} 


\section{Introducing a didactic experiment}

To address this lacuna, we introduced a new didactic experiment for embedding built heritage values into the architectural design process of the H\&A graduation studios. These studios are open to international students with at minimum a Bachelor degree in architecture. Because not everyone is familiar with heritage conservation theory when entering the H\&A graduation studios, a sort of crash course had to be drafted, partly coupled with lectures and reading assignments and merged with the specific challenges of both understanding the place and 'redesign'. To this end, we tailored a single step-by-step method that appeals to the full diversity of the student body, for which the application of a 'Heritage Value Matrix' (HV-Matrix) is an essential tool. This matrix, further expanded on below, invites students to make use of visual elements (photos, drawings, symbols) alongside, or instead of, wording to express heritage values-first in small groups and later individually. The didactic experiment was aimed at the iteration of the heritage valuation process and tools across a range of built heritage types, with a range of primary and secondary sources.

The iterative process, with built-in assessment, was applied as first trial in parallel in three H\&A studios, starting in the fall of 2016. These addressed different types of built heritages: twentieth century industrial architecture built into medieval fabric in Lisbon, Portugal ${ }^{2}$ the late-nineteenth and early twentieth-century harbour buildings in Rotterdam and non-traditional Dutch housing construction systems dating from the 1950s to the 1970s. The didactic experiment and interim results were evaluated through both peer review (internally and internationally) and post-application client (student) evaluation. The method and tools were presented and discussed in plenary at a special H\&A section meeting on education, leading to a wider acceptance with some amendments. ${ }^{3}$ It was further presented as conference paper to international peers in heritage conservation, who responded very positively to the combination of graphical analysis, iterative design steps and interim discussions. ${ }^{4}$ General student evaluations followed at the end of that academic year (mid-2017), by means of an online survey utilising Google-Forms (www.docs.googl e.com). These were directed at student participants of the pilot studios over 2016-2017. Responses were voluntary and anonymous. Students were asked to rate neutral statements such as 'The Cultural Value Matrix is..." with a sliding scale of $1-5 ; 1$ being 'user unfriendly' and 5 being 'user friendly', or 'The (extended-) Cultural Values as described by Riegl are, in a contemporary context...' 'not applicable' (1) to 'very applicable' (5). Students were also asked for general feedback, tips for improvement and opinion.

The method and tools were further tested by the architectural students participating in the international workshop 'Education to Everybody/Structures in Ljubljana' as part of the 15th International Docomomo Conference 'Metamorphosis-The Continuity of Change'. Participants embraced the structured process of observation and analysis of built heritage

\footnotetext{
2 The interim results of the valuation laboratory by the students of the 'Lisbon Studio' were selectively published as demonstration models for future H\&A students (Kuipers and De Jonge 2017).

3 This special plenary discussion on design education included all educational and research staff of the three chairs of Heritage and Design, Heritage and Technology and Heritage and Values and was held at the TU Delft on 31 January 2017.

${ }^{4}$ Presented at the 2017 Intangibility Matters IPERION CH International Conference on the Values of Tangible Heritage at LNEC in Lisbon, Portugal (Clarke and Kuipers 2017).

5 The HV-Matrix was initially referred to as the Cultural Value or CV Matrix.
} 
sites by using the HV-Matrix and other tools enthusiastically. ${ }^{6}$ Early in 2019, the method and tools were again presented for plenary discussion at a study day on values and attributes at the TU Delft. A significant topic of discussion here was the importance of selecting applicable values (especially for students lacking a heritage theory background) and scalability of the values and tools to other built-environment scales such as the interior and (urban-) landscapes. ${ }^{7}$

\section{The challenge of embedding heritage values in architectural design education: the state of the art}

According to (Mason 2005, p. 5), value assessment presents a threefold challenge for purposes of planning and management: 'identifying all the values of the heritage in question; describing them; and integrating and ranking the different, sometimes conflicting values, so that they can inform the resolution of different, often conflicting stakeholder interests.'

The range of values ascribed to built fabric today was developed over more than a century. These were first cohesively described by Riegl (1903/1996), a prominent Austrian art historian and State conservator. His theory on the modern cult of monuments remains relevant to a wide international audience. Many others have revised, consolidated or augmented his dialectic system of heritage values (Mason 2005; Pereira Roders 2007; Drury et al. 2008; Meier et al. 2013; Halbertsma and Kuipers 2014). Riegl defined two oppositional categories: commemorative values, including 'age value', and paradigm-bound present-day values, the latter including relative aesthetic value as well as 'use value'. These have consequences for dealing with the heritage site.

In the built environment these heritage values together inhabit an 'ecology of ideas' as defined by Bateson (1972), and relate to buildings as individuals where, to paraphrase Bateson's term 'schismogenesis' (Bateson 1936/1958, p. 175): the differentiation in the norms (which we understand as values) ascribed to individual buildings result from the cumulative interaction between people (both thinking on and doing with) and buildings over time. This necessitates two perspectives when dealing with values in the built environment: (1) allowing for the emergence of values over time, i.e. not being dogmatic about prescribed values, and (2) developing an eco-systemic perspective on buildings in context. This means that we need to find ways of relating these 'ecology of value-ideas' to physical fabric.

A quality often valued, but difficult to describe is that of 'authenticity'. This rather elusive concept was unpacked in the ICOMOS (1994) Nara Document on Authenticity, which in turn led to the development by Van Balen (2008) of the so-called Nara Grid. This matrix attempts to link authenticity as quality (or value) to physical aspects of a building. The Nara Grid forms an important precedent as approach to systematise non-tangible aspects of value in relation to built heritage.

Many guidelines exist to aid professionals, often building archaeologists, in evaluating existing buildings. Such guidelines, which also exist for the Netherlands (Hendriks and Van

\footnotetext{
6 Oral communication with Marieke Kuipers during the workshop and 15th International Docomomo Conference, held 24-28 August 2018 and 28-31 August 2018, respectively; see also http://www.rmb-eu.com/ international-student-workshop-in-ljubljana and (Tostões and Koselj 2018).

7 Chair of Heritage and Values study day titled 'Significance: Values and Attributes', TU Delft, 26 March 2019.
} 
der Hoeve 2009; Stenvert and Van Tussenbroek 2015, 2016), include the physical analysis of extant built form. These address the realm of the architectural historian or building archaeologist, and indicate those physical elements of a monument or building are deemed to be conservation-worthy based on age, scientific, historical, aesthetic qualities, rarity, or other associations. They generally do not speak to the non-tangible aspects, such as spatial qualities, spirit of place or other (socio-) cultural associations.

Importantly, all these value descriptions form systems of enquiry with a focus on the cultural (historical), and do not address the complexity of often conflicting forces the architect is faced with when designing an intervention in existing fabric (such as economics, comfort or energy efficiency requirements, etc.). Nor are they, in general, intended to engage with the design process of the architect entrusted with the redevelopment of extant buildings.

There are noteworthy parallels between the design process and the valuation process of heritage buildings. Design processes differ depending on the designer and the assignment; designers do not necessarily work from the outline to detailing but switch between different domains and levels of detail. Nevertheless, three main stages can be identified in the design process: analysis, synthesis, and evaluation (Lawson 2005). This echoes the valuation process where primary sources are interrogated, these amalgamated and then evaluated. This is a subjective process that requires objective verification, because 'values are produced out of the interaction of an artifact and its contexts; they don't emanate from the artifact itself' (Mason 2005, p. 8). In the process of valuation, as in the design for adaptive reuse of an existing structure, the built artefact (building) itself forms the primary source. Like the process of valuation, the design process is also generative and therefore subjective (Groat and Wang 2002) but informed by an array of traceable, external sources. While fully acknowledging the subjectivity of values in general, the designer must develop an objective position with regards to those values of a building they have been entrusted with.

The obligation to safeguard values often generates a direct dilemma when new programmatic requirements are set. Hence, understanding the concept and meaning of different built heritage values (theoretical frameworks) and their significance are an essential source for the assignment of adaptive reuse. Compared with other courses in the field 'education for reuse' there is consensus that a thorough analysis of the history, the spatial and technical state, the original design ideas etc. and the heritage values of the existing building to be adapted is needed as sound knowledge base for any intervention proposal (Zijlstra 2009; Kuipers 2010; Moniz et al. 2016). Our challenge goes beyond those of 'reading', identification, planning for conservation, interpretation and understanding of setting, good research practice, ethics, diagnostics of decay and presentation and communication of findings that underlie the ICOMOS (1993) 'Guidelines for Education and Training in the Conservation of Monuments, Ensembles and Sites.'

\section{The cultural value approach in the context of the H\&A graduation studio}

The educational challenge presented by the current Chair of Heritage and Values is to engender an understanding of the built heritage values, assist students to analyse and subsequently employ these values as design informants and generators for design ideas-in the words of Norman Foster 'inspiration for the future' - through a systematic design-aligned process. Next to that a framework for self-, peer and didactic evaluation and justification 
should be provided. ${ }^{8}$ At the same time, such a process should fit seamlessly into the preexisting graduation studio structure of $\mathrm{H} \& \mathrm{~A}$.

The structure of the cultural value approach we developed is:

- Discovering and visually locating built heritage values [Analysis]

- Relating (intangible) heritage values to physical structures [Analysis and Synthesis]

- Prioritizing heritage values and identifying opportunities for intervention in order to support and guide design decisions [Analysis and Synthesis]

- Integrating heritage values into design proposal(s) throughout the entire design process (develop creative strategies to conserve, enhance, make tangible) [Synthesis]

- Reflecting on the success of the integration as further informant to the iterative design process [Evaluation]

There are limitations to what can be accomplished in a single graduation project. Architectural students are not trained to become architectural historians or building archaeologists and this should not be the ambition for the architect (Van Emstede 2014). This means that students need to rely on available information such as extant building archaeological surveys and other literature to inform their own assessment. We are cognisant 'that no single discipline or method yields a full or sufficient assessment of heritage values; therefore, a combination of methods from a variety of disciplines should be included in any comprehensive assessment of the values of a heritage site' (Mason 2005, p. 6). The limited time available to embed built heritage values into the design process also means that we have to accept that students' knowledge about these values will not be complete or exhaustive at the end of the course. We also have to accept that we are dealing with a limited scope of values, often neglecting the integration of social and economic values, which in real world situations would be unavoidable. It is also not always practicable to ensure interaction with other stakeholders involved - an important aspect of both real-world valuation and architectural practice. A final consideration of importance is that, due to a variance in the topics of studios, any process developed to embed heritage values in a design studio should remain flexible.

Tutors from all the chairs of the section H\&A collaborate in the H\&A graduation studio and share the responsibility for delivering graduate architects with specialisations in 'Heritage and Architecture'. The first quarter of the course (which in total consists of four quarters of 10 weeks each) is dedicated to analysing constraints, challenges and opportunities of the assignment in which the value assessment of the existing structures is a focal point of the student's research.

\section{Step-by-step process of assessing and embedding cultural values}

In the H\&A graduation studios, students are expected to deliver a single coherent architectural proposal relying, to a large extent, on the successful integration of architectural, technological and cultural values. Because this is a complex task we have defined a step-by-step

\footnotetext{
${ }^{8}$ See for study goals the course descriptions (retrieved 2017-10-02): http://www.studiegids.tudelft.nl/ a101_displayCourse.do?course_id=41923, http://www.studiegids.tudelft.nl/a101_displayCourse.do?cours e_id $=41920$.
} 


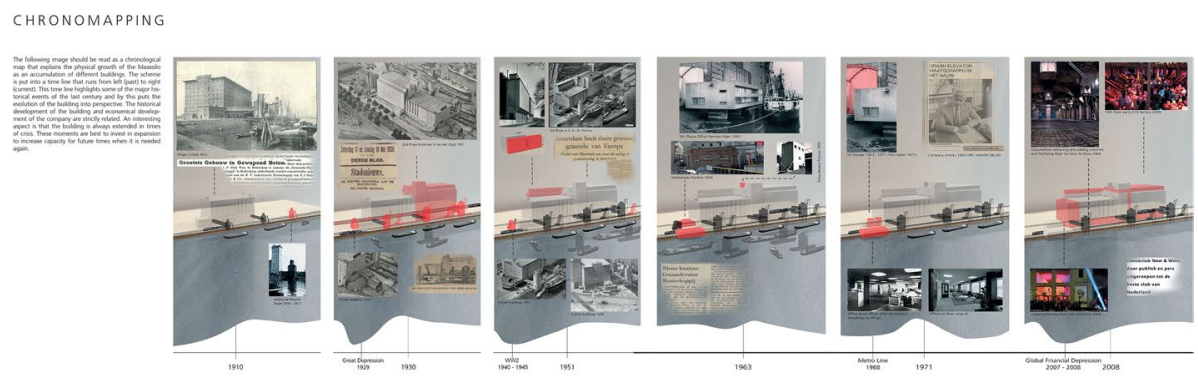

Fig. 1 Chrono-mapping of the Maassilo complex at Rotterdam (2017, Rotterdam Harbour Heritage studio work by H\&A students S. Bruinsma, K. Vatanidis \& D. Van Weeghel)

process, with the use of specific tools presented as part of the discovery and analysis processes prior to the design assignment:

\section{Discovering values [Analysis]}

To discover values, a strong emphasis is placed on the analytical phase, during which interrelated analyses on the architectural, technological and cultural value aspects of the building or site and its urban, topographical and geographical context are undertaken. Students work in small groups of 3-5 students in order to achieve more depth in their analysis and to stimulate a debate on values and their significance. Students quickly realise that the fields form an integral whole: a technically important aspect like a historic timber roof structure can, for instance, have historical value and be of significance to the architectural expression at the same time.

A heritage and values tutor is assigned to each H\&A studio to guide and demystify the complex process of detecting heritage values. The process of built heritage value analysis follows a mix of standard 'interpretative research' methods. We start with primary sources (Groat and Wang 2002): searching for and analysing archival sources coupled with observation. Field inspection has been given a special place in our methodology because the building as artefact forms the primary source. To enforce this select position of 'observation' in the toolkit of the aspiring H\&A architect, Kuipers developed the process of 'building anamnesis' as guide to assist students to ensure observation takes place on a range of scale levels (Kuipers and De Jonge 2017). This system of anamnesis of the building in its current state follows and expands on the 'shearing layers' system that Steward Brand developed to describe the rates of change in buildings (Brand 1995). Brand's system provides an elegant way of analysing buildings in relation to time through pre-defined layers.

The factor of time also needs analysis. The compilation of timelines helps to understand a building's evolution, including its cultural historical and topographical setting, and to unlock the age-values - a fundamental heritage value-of various aspects. Mapping of the building phases is undertaken to deeper understand the building as a palimpsest of interventions over time (Hendriks and Van der Hoeve 2009). We have chosen to call this 'chrono-mapping'. Chrono-mapping represents the building artefact itself as a timeline of interventions, either in stages, or superimposed onto its current manifestation (Fig. 1). Chrono-mapping makes no value judgement, but presents a built-fabric chronology without 


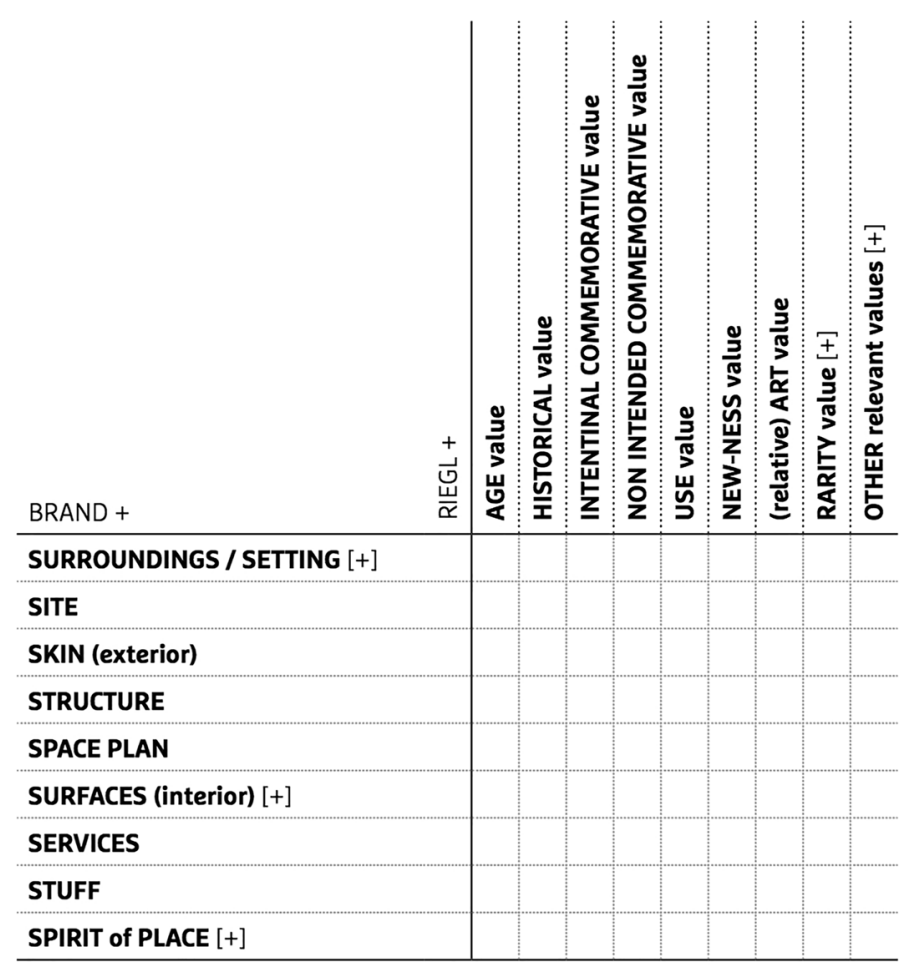

Fig. 2 The updated version of the Heritage Value Matrix after one year of testing in the architectural design education in H\&A graduation studios (Clarke and Kuipers 2017)

any other interpretation. It allows for the discovery of that which is and also that which was, revealing lost elements, forms and spatial relationships, all of which not only inform the analysis of values, but could possibly serve as design generators.

Secondary sources, writing, research reports, interviews with specialists and affected parties all further illuminate the subject under investigation. However, a systematic synthesis is required to distil these into a manageable dataset.

\section{Relating (intangible) heritage values to physical structures [Analysis/Synthesis]}

To support the process of identification and interpretation we introduced the HV-Matrix (Fig. 2). ${ }^{9}$ This didactic tool was developed to bring intangible values into direct relationship with the scope of impact of the architect: the built fabric. The use of matrixes allows for both structuring and synthesising - as evidenced for instance in their use of the Nara Grid (Van Balen 2008) and the ABCD-Time method (Zijlstra 2009). In the HV-Matrix, Steward Brand's shearing layers-system (extended) forms the structuring for the physical

\footnotetext{
${ }^{9}$ Nicholas Clarke with Prof Marieke Kuipers (both of the Chair of Cultural Heritage) developed the first version during 2016 in collaboration with Dr. Hielkje Zijlstra of the Chair of Heritage and Design at the TU Delft.
} 


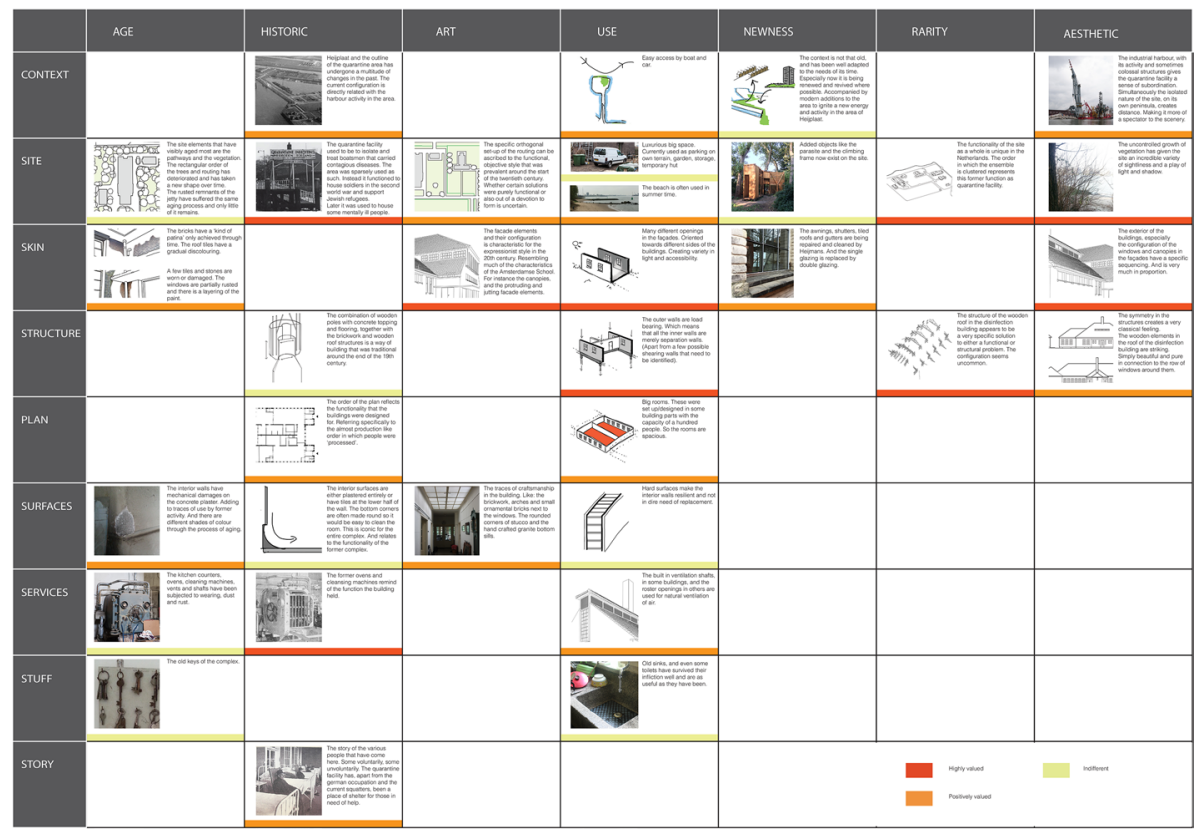

Fig. 3 An extended Heritage Value Matrix applied on the former quarantine complex of the Rotterdam harbour. Values are prioritized by the stoplight system $(2017$, Rotterdam Harbour Heritage studio work by H\&A students T. Sandfort \& J. Verhoef)

aspects of the building (on the vertical axis): Surroundings, Site, Skin, Structure, Space plan, Surfaces (interior), Services and Stuff. On the horizontal axis a range of built heritage values is positioned. Matter and meaning are brought directly into relationship in this predefined way, to be further elaborated in the cells of the matrix.

During the first experiment, the HV-Matrix was prepopulated with the dialectical system of values in monuments as described by Riegl and students were encouraged to populate those cells where meaning and matter were found to meet with illustrations and text. In full cognisance of the value of graphic presentation as representing a certain kind of architectural knowledge (Kirkeby 2010), we stimulated students to apply architect's skills and tools by using sketches, diagrams, drawings, icons and own photographs to illustrate values, especially where these can be related directly to physical or spatial qualities of the heritage building (Fig. 3). Students were also actively encouraged to argue for extending the field of values where they saw fit, honing their understanding of specific values. This exercise is an act of synthesis of observation and analysis as well as a first attempt at assessment.

\section{Prioritizing built heritage values and identifying opportunities for intervention in order to support and guide design decisions [Evaluation]}

Once a defendable position-not necessarily consensus-has been reached regarding the embodied values of a place and their relationship to physical fabric, they need to be prioritised. This can be done by means of a number of classifications, which are 


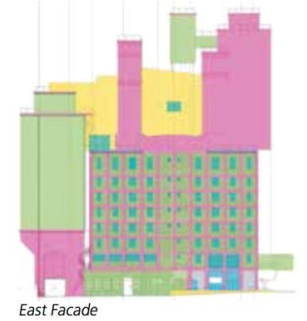

Preserve and conserve in original state. These elements are essential for the experience of
the silo complex and are of great historical

Redevelopment is possible with to the orignal structure and materialisation The origin design ideas should remain readable.

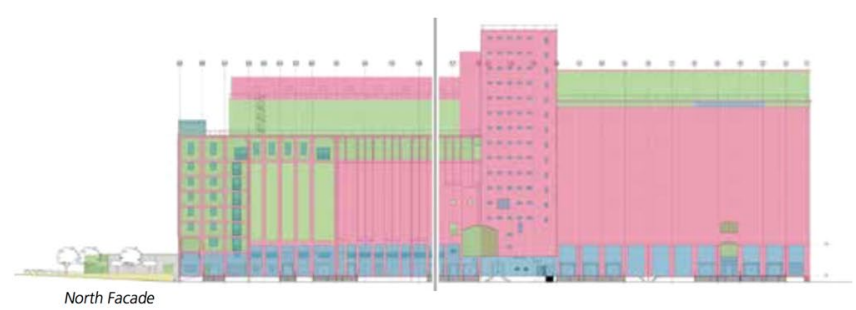

Maintain if possible These aspects contribute to the total understanding of the ensemble.

These elements interfere with the total un. derstanding of the complex. When intervening in these parts it should be designed

Fig. 4 Students' cultural value assessment conclusion for two facades of the Maassilo in Rotterdam-a good basis from which to plan a values-driven intervention (2017, Rotterdam Harbour Heritage studio work by H\&A students S. Bruinsma, K. Vatanidis \& D. Van Weeghel)

not mutually exclusive: significance, rarity, strength, vulnerability, visibility and flexibility or elasticity. A first step is assigning significance: a process that is also subject to peer debate, but not necessarily consensus. A simple way of doing this is assigning colour-coding to cells of the matrix, using a 'stop-light' system: red for high, yellow for medium and green for low significance. Again it must be stressed that high significance, for instance, does not indicate a no-go-area, but rather that more care is required in intervention planning to ensure the retention of value, or adequate mitigation if the value has to be sacrificed.

\section{Integrating built heritage values into the design proposal and reflection [Synthesis/ Evaluation]}

The HV-Matrix abstracts the heritage building into layers and values and helps to prioritise values. To synthesise information on values in relation to the building as an artefact requires that the step be made back to the scale of building as artefact within its context. Students are therefore tasked to compose a textual statement of significance-a concise textual statement in which built heritage values are identified and described in relation to built fabric and resulting spaces - as product, along with drawings of the building (preferably three-dimensional projections) that illustrate areas or elements of significance (Fig. 4). In addition, they also need to identify:

- Opportunities (where to intervene, what to improve),

- Obligations (handle with care, conserve)

- And dilemmas (which values conflict with each other or with programmatic or economic requirements), analyses.

...with regards to the inherited building and its continued use arising from their

These form the main Cultural Value informants in the generative iterative design process and provide the baseline for assessing their final designed graduation project. Therefore, 
and to avoid that a (student) designer is biased by his or her design ambitions, it is crucial that the analysis and assessment of built heritage values is conducted before the actual design phase starts.

\section{Educational research approach}

A structured process is now employed to embed built heritage values into the design education of the H\&A graduation studios. The educational method requires students to undertake group- and individual research, supported by a combination of:

- An introductory lecture and workshop to introduce the theory of heritage valuation and the concept and work method of the H\&A cultural value approach as most students are not familiar with the underlying theoretical framework,

- On-site investigations undertaken with experts from practice and tutors to conduct building anamnesis and strengthen the link with practice,

- Self-study:

- Individually: literature, including Riegl (1903/1996) and Brand (1995); research in primary and secondary sources, archives, research reports etc. on the study-subject,

- In peer groups: chrono-mapping (collecting information and visualizing), assessing values with the cultural value matrix,

Group work is done for two reasons: sharing work load in order to collect more indepth information, and, to facilitate peer review.

- Tutoring in a studio setting provides structured feedback and guidance (weekly).

To guard against opportunism when defining values we apply three tools:

- Extant sources (pre-existing value assessments including those in monuments registers and relevant literature),

- Peer review, and

- Tutor evaluation.

Peer review of the HV-Matrices by means of workshops has proved to be indispensable in refining the values and their relationship to the built fabric under investigation and is now a crucial component in our educational methodology. Peer discussions also provide an important environment for engagement with colleague-students. In this process students learn to evaluate, present, and discuss values, and ultimately to understand that values, including built heritage values, can be perceived and evaluated differently by different persons and disciplines at different periods in time. Assessment takes place through weekly tutor evaluation and written feedback on, initially, a draft (after two-thirds of study-time), and a final report in which the architectural culturally important values are linked to the attributes of a building and its location. 


\section{Lessons learnt}

The development of the methodology for embedding heritage values in architectural design education was designed as an iterative experiment. The step-by-step process outlined above was based in our analysis of needs and extant literature, synthesised into a set of tools to be employed in a pre-defined process. This was tested in the H\&A graduation studios, which acted as laboratory.

Both evaluation of process and tools took the form of internal review, peer review and client-directed questionnaires, aimed to validate and refine the method.

Based on the first results, our own internal evaluation concluded that ' $\mathrm{t}] \mathrm{he}$ Heritage Value Matrix allows us to go beyond the level of narration that is the aim of interpretative historical research [...] and generates an interrelational fabric-, spatial- and value based assessment that provides a framework for assessment of the impacts of design interventions' (Clarke and Kuipers 2017, p. 207). During an internal review within the larger H\&A section, structured as a presentation and discussion session, the exclusive application of the Rieglian value-set in the HV-Matrix was openly questioned while being appreciative of the process in general. However, an alternative - universally applicable — set of heritage values was not provided, let alone commonly accepted. So the decision was made to continue the Rieglian value set, albeit with the opportunity to question its application, alter or extend it, or reject it, if based on validatable argumentation.

The reception of the newly developed process was assessed by a post-application online questionnaire amongst students. A total of 24 students from a body of 39 H\&A studio participants responded to the questionnaire (62\%). Of these the majority had completed their undergraduate at the TU Delft (66\%). Nearly half of (41\%) the respondents had not followed an H\&A Master 1 or Master 2 module. The results of the questionnaire proved to be very illuminating. This questionnaire showed that the majority of students valued the value analysis and assessment process highly and found that the Cultural Value assessment and the definition of obligations and opportunities influenced their design process in a positive

The impact of the Cultural Value assessment on my desing proposal was:

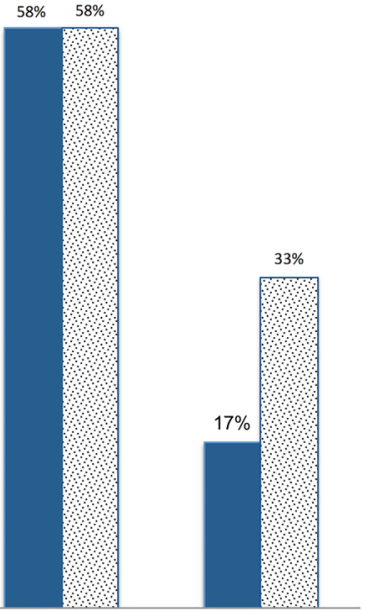

Low / Disagree High / Agree

Fig. 5 Students' own perception of the impact and contribution of Cultural Value assessment in their final designs, as reported to through the anonymous voluntary questionnaire, 2017 
- The HV-Matrix as structure for analysis is:

0. The HV-Matrix as tool to stimulate insightful group discussion is:

The HV-Matrix as tool to identify dilemmas between cultural values and (new-) use for adaptive re-use design is:

- Using the HV-Matrix as tool to identify opportunities and obligations with regards to cultural values and new use is:

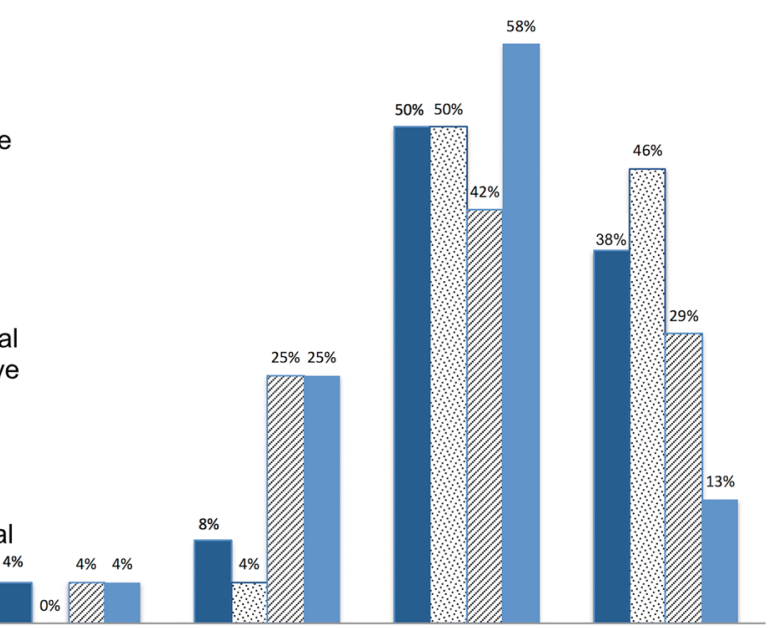

Not useful $\leftarrow----------------\rightarrow$ Very useful

Fig. 6 Results of the evaluation, by means of an anonymous voluntary questionnaire of the usefulness of the HV-Matrix by students, 2017

way (Fig. 5). Furthermore, they appreciated the chrono-mapping and HV-Matrix tools specifically as useful instruments (Fig. 6). As one respondent-student stated: 'Looking back at my design and how I used the defined cultural values in my graduation project I found that whenever I was stuck in the design I had to go back to the cultural values to refresh and reshape what I value and why. This helped to make design decisions starting from the existing. The heritage actually provides all the tools to design, but you really have to delve into it first and get to know the buildings.'

All respondents found that the HV-Matrix provided a useful way to relate the physical fabric of a building to the meaning of its built heritage value. Or as one student put it: 'The Matrix stimulates the discussion with other group members to consider the Cultural Value from small- to large-scale. By using the Matrix, I can organise the things that I found from the research in an effective way.' The HV-Matrix was found to make the building being investigated ' $[. .$.$] understandable and approachable even if certain aspects are com-$ plicated.' Another respondent-student waxed more lyrical, appreciating: '[t]he preciseness that the matrix has because of the combination of the Riegl Values and the Brand Layers. The layers of Brand let you pinpoint elements and simultaneously understand if they are probably old or newer since the layers are about time. The matrix is in my opinion a rough instrument like the builder's hammer as well as being delicate like a sculptor's chisel. You can value the entire concrete structure as well as a tile plaque in the same scheme.'

The last-quoted student also responded succinctly to the HV-Matrix by appreciating: ' $\mathrm{t}$ ] he simplicity of it. ${ }^{10}$ Most of the students agreed with the statement that 'The CV Matrix should be introduced earlier in the architectural education of H\&A.' On a scale of 1-5, $29 \%$ strongly agreed with the statement, $37 \%$ agreed and only $8 \%$ did not agree.

\footnotetext{
10 These were responses to the question: 'What did you appreciate about the Cultural Value Matrix in particular?'.
} 


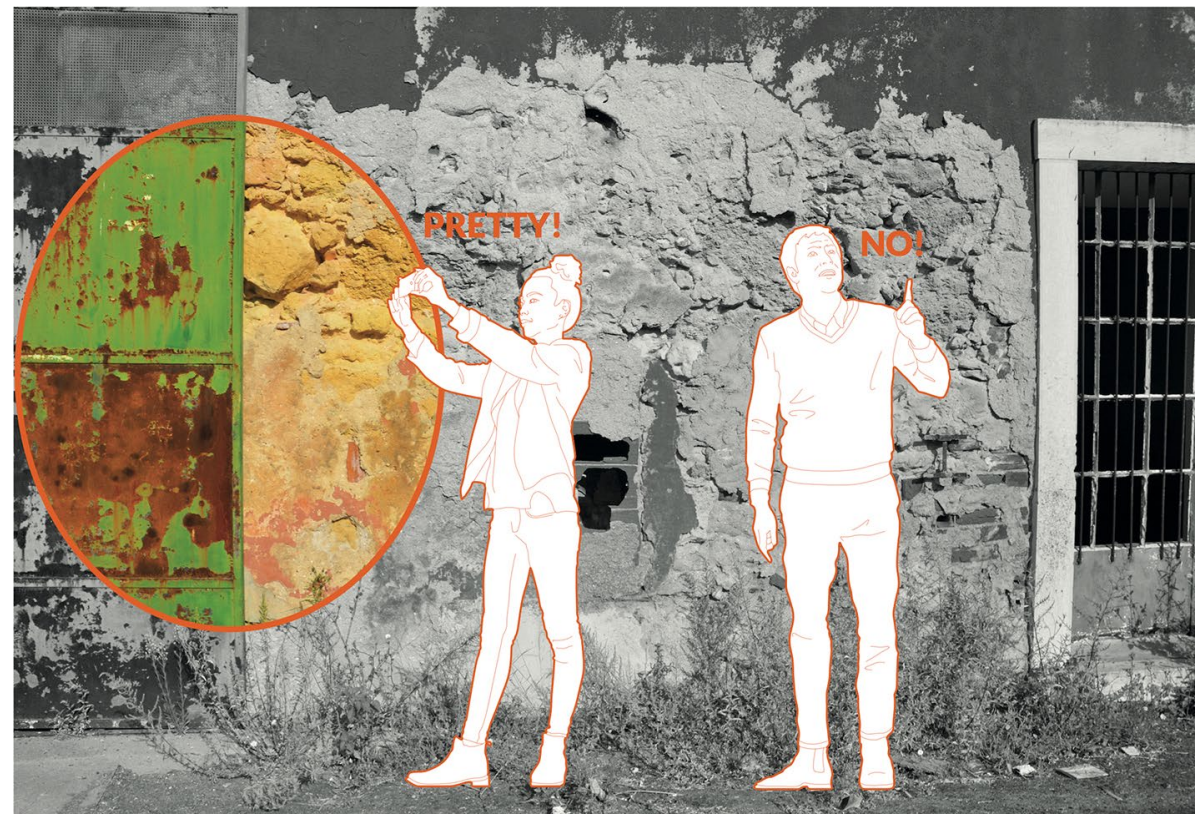

Fig. 7 The dilemma of conservation of decay [age value] versus repair [aesthetical newness value] (2017, Lisbon studio work by H\&A student M. Byra)

Using the extended version of Brand's shearing layers model to structure the physical aspects of the building was well received. Following the first experimental rollout of the process, students however requested more flexibility in the definition of values, along with more time for tutors to present different (concepts) of values and unpack these. For many, this had been their first introduction to the concept of heritage value. Not only did they need to come to terms with a new discipline, they were also required to implement it critically and across ranges of scales in an iterative process that ultimately had to lead to presenting a graduation project. It is no wonder then that many felt that the concept of built heritage valuation, the specific understanding of values and the HV-Matrix should be introduced earlier in their architectural education, thereby offering opportunities for adjustment and wider integration in further H\&A courses.

The usefulness of the HV-Matrix as a pre-defined yet versatile tool to reduce and synthesise complexity in education practice was proven. This is especially important in situations (like ours) where the entry levels of students concerning the role of heritage values in re-use projects vary significantly. We have learnt that a lot more needs to be done in terms of contact time, be that through workshops, lectures, or individually, to embed a heritage values-based approach in design education. A special quality of the HV-Matrix, also appreciated and preferred by students-who are adept at combining visual and textual communication methods-is that it couples cerebral and visual thinking by including both illustrations (sketches, drawings, diagrammes etc.) and textual descriptions. Using images/ illustrations within matrixes proved to be very appropriate in (architectural-) design education. Buildings are, after all, physical and spatial creations, and drawings/diagrammes are the most direct abstraction of the qualities of these artefacts. 


\section{Critical evaluation}

In retrospect, we have concluded that the methodology and tools for detecting and embedding built heritage values were well received by H\&A students, even if not always fully understood. The process added quality to the final graduation designs, enriching the design process by providing seeds for generative and iterative design explorations. The use of the tools especially nurtured collaborative analysis and stimulated debate. The method also provided a solid basis for evaluation for both students and tutors: The HV-Matrix in combination with prioritising values, chrono-mapping and defining of opportunities, obligations and dilemmas (Fig. 7), allows for continuous evaluation and reflection throughout the design development process, serving as anchor for the student.

We have found that actively assessing built heritage values as integral part of the design education of future architects contributes towards design process and reuse proposals in a positive way, even when some values are not fully comprehended. It imbues the globally accepted 'cautious approach' (ICOMOS 1999) when dealing with places of significance and helps value those aspects of places that are considered heritage, even where they have not been identified as such explicitly by others before.

The current trend to establish interdisciplinary approaches in education offers opportunities for a heritage values-based design education as well. Collaboration with allied disciplines, such as social sciences or real estate management, could lead to even more comprehensive assessment of the built heritage values in the future.

The use of the extended Rieglian values system has proven to be useful, although the level of abstraction and the conflicts embedded in its dialectic structure can be difficult for students to internalise and work with. The criticism of students and peers was therefore valid. Nevertheless, there are hardly any other value-sets that can be universally applied in view of design decisions related to reuse. It is exactly the multiplicity of perspectives embodied in the Rieglian value system that keeps it applicable and instructive: How does one for instance deal with age value, as represented by patina, when also having to guard the aesthetic and use value of a structure? These are useful questions to ask. At the same, time students had difficulty filtering out values that were not present in a building, searching for imaginary needles in haystacks. This sometimes led to forced positions being taken - an avoidable situation. To reduce possible confusion, we now present students with the matrix without any pre-defined values, and allow them to distil a set of values from selected literature that is applicable to the subject at hand.

Another point of concern is that in this approach, students themselves create their values-based points of departure. This can result in opportunist 'cherry-picking' and biased perspectives. In reality it is preferable that independent valuators develop value statements to which architects respond (Roos 2007; Hendriks and Van der Hoeve 2009; Poulios 2014; Meurs 2016). Our aim remains not to teach the students to compose legal or art-historical assessments, but how to assimilate these and other built heritage values into a design decision-guiding framework and an architectural (intervention-) strategy. That is why we apply our step-by-step built heritage approach and how we embed an understanding of these values in our architectural design education.

As we have seen, students also credited the Cultural Value Assessment process as having a positive impact on their design projects. We therefore conclude and argue that the Chair of Heritage and Values has a greater role to play in education of architects at the TU Delft and we propose a programme be developed as foundation course at the Faculty of Architecture. Graduate education serviced by the Chair will still be required, 
to further explore concepts, but also to accommodate students entering graduate courses from other institutions.

Open Access This article is distributed under the terms of the Creative Commons Attribution 4.0 International License (http://creativecommons.org/licenses/by/4.0/), which permits unrestricted use, distribution, and reproduction in any medium, provided you give appropriate credit to the original author(s) and the source, provide a link to the Creative Commons license, and indicate if changes were made.

\section{References}

Bateson, G. (1936/1958). Naven: A survey of the problems suggested by a composite picture of the culture of a New Guinea tribe drawn from three points of view. Cambridge: Cambridge University Press/ Standford: Standford University Press.

Bateson, G. (1972). Steps to an ecology of mind: Collected essays in anthropology, psychiatry, evolution, and epistemology. Northvale: Jason Aronson.

Brand, S. (1995). How buildings learn: What happens after they're built. London: Penguin Books.

Clarke, N. J., \& Kuipers, M. C. (2017). Introducing the heritage value matrix: Connecting matter and meaning in built heritage. In M. Menezes, D. Rodrigues Costa, \& J. Delgado Rodrigues (Eds.), Intangibility matters: International conference on the values of tangible heritage (pp. 207-216). Lisbon: Laboratório National de Engenharia Civil, I. P.

Cramer, J., \& Breitling, S. (2012). Architecture in existing fabric: Planning, design, building. Basel: De Gruyter.

Drury, P., McPherson, A., \& Heritage, English. (2008). Conservation principles: Policies and guidance for the sustainable management of the historic environment. London: English Heritage.

Groat, L., \& Wang, D. (2002). Architectural research methods. New York: Wiley.

Halbertsma, M. E., \& Kuipers, M. C. (2014). Het erfgoeduniversum: een inleiding in de theorie en praktijk van cultureel erfgoed. Bussum: Coutinho.

Hendriks, L., \& Van der Hoeve, J. (2009). Guidelines for building archaeological research the interpretation and analysis of cultural-historical heritage. Amersfoort: Cultural Heritage Agency.

ICOMOS. (1993). Guidelines for education and training in the conservation of monuments, ensembles and sites. Colombo: ICOMOS.

ICOMOS. (1994). Nara document on authenticity. Nara: ICOMOS.

ICOMOS. (1999). The Burra charter: The Australia ICOMOS charter for places of cultural significance. Burra: ICOMOS.

Kirkeby, I. M. (2010). Knowledge in the making. Architectural Research Quarterly, 13(3-4), 307-313.

Kuipers, M. C. (2010). The architectural memory. Delft: VSSD.

Kuipers, M. C., \& De Jonge, W. (2017). Designing from heritage: Strategies for conservation and conversion. Delft: TU Delft-Heritage \& Architecture.

Lawson, B. (2005). How designers think: The design process demystified. Amsterdam/Boston: Elsevier/ Architectural Press.

Mason, R. (2005). Assessing values in conservation planning: Methodological issues and choices. In M. De la Torre (Ed.), Heritage values in site management: Four case studies (pp. 5-30). Los Angeles: Getty Conservation Institute.

Meier, H.-R., Scheurmann, I., \& Sonne, W. (Eds.). (2013). Werte. Begründungen der Denkmalpflege in Geschichte und Gegenwart. Berlin: Jovis.

Meurs, P. (2016). Heritage-based design. Delft: TU Delft - Heritage \& Architecture.

Moniz, G. C., Quiroga, C., \& Pottgiesser, U. (2016). Education for reuse (Session 25). In A. Tostões, \& Z. Ferreira (Eds.) Adaptive reuse: The modern movement towards the future. (pp. 830-867). (Docomomo 14th International Conference, Lisboa, 2016). Lisboa: Docomomo International/Casa da Arquitectura.

Pereira Roders, A. R. (2007). Re-architecture: Lifespan rehabilitation of built heritage-capitellum. Eindhoven: Technische Universiteit Eindhoven.

Poulios, I. (2014). Discussing strategy in heritage conservation: Living heritage approach as an example of strategic innovation. Journal of Cultural Heritage Management and Sustainable Development, 4(1), $16-34$.

Riegl, A. (1903/1996). Alois Riegl. The modern cult of monuments: Its essence and its development. In Price, N. S., Kirby Talley Jr., M., \& Melucco Vaccaro, A. (Eds.) (1996). Historical and philosophical 
issues in the conservation of cultural heritage (pp.69-83). Los Angeles: The Getty Conservation Institute.

Roos, J. (2007). The discovery of the assignment. Delft: VSSD.

Rosenfield, K. (2014). Norman Foster's Interview with the European: "Architecture is the Expression of Values". http://www.archdaily.com/563537/interview-norman-foster-on-the-role-of-architecture-inmodern-society/. Accessed 28 Sept 2017.

Stenvert, R., \& Van Tussenbroek, G. (Eds.). (2015). Inleiding in de Bouwhistorie: Opmeten en Onderzoeken van Oude Gebouwen. Utrecht: Matrijs.

Stenvert, R., \& Van Tussenbroek, G. (Eds.). (2016). Het Gebouw als Bewijs: Het Bouwhistorische Verhaal achter Erfgoed. Utrecht: Matrijs.

Tostões, A., \& Koselj, N. (Eds.) (2018). Metamorphosis. The Continuity of change. (15th International Docomomo Conference, Ljubljana, 2018) Lubljana: Docomomo International.

Van Balen, K. (2008). The Nara grid: An evaluation scheme based on the nara document on authenticity. APT Bulletin, 39(2-3), 39-45.

Van Emstede, C. I. C. (2014). Waardestelling in de Nederlandse Monumentenzorg 1981-2009. Delft: Delft University of Technology, Faculty of Architecture and the Built Environment.

Van Hees, R. P. J., Naldini, S., \& Roos, J. (2014). Durable past-sustainable future. Delft: TU Delft - Heritage \& Architecture.

Zijlstra, H. (2009). Analysing buildings from context to detail in time: ABCD research method. Amsterdam: IOS Press.

Publisher's Note Springer Nature remains neutral with regard to jurisdictional claims in published maps and institutional affiliations. 